\title{
Carbon Storage on Different Species of Seagrass on Tourist Destination Areas: A Measure of Disturbed and Undisturbed Environments
}

\author{
Ni Luh Watiniasiha, ${ }^{\mathrm{a}}$, I Wayan Nuarsa ${ }^{\mathrm{b}}$, I Made Merdana ${ }^{\mathrm{c}}$, Agus Dharma ${ }^{\mathrm{d}}$, I Nyoman Gde Antara ${ }^{\mathrm{e}}$, \\ I Nyoman Budiarsa ${ }^{\mathrm{e}}$ \\ ${ }^{a}$ Department of Biology, Faculty of Mathematics and Natural Sciences, Udayana University, Kuta, Bali, 80361, Indonesia \\ ${ }^{b}$ Department of Marine Sciences, Faculty of Marine and Fisheries, Udayana University, Kuta, Bali, 80361, Indonesia \\ ${ }^{c}$ Department of Physiology and Pharmacy, Faculty of Veterinary Medicine, Udayana University, Denpasar, Bali, 80225, Indonesia \\ ${ }^{d}$ Department of Electrical Engineering, Faculty of Engineering, Udayana University, Kuta, Bali, 80361, Indonesia \\ ${ }^{e}$ Department of Mechanical Engineering, Faculty of Engineering, Udayana University, Kuta, Bali, 80361, Indonesia \\ Corresponding author: *luhwatiniasih@unud.ac.id
}

\begin{abstract}
Carbon absorption and storage, known as carbon sequestration, have reduced global warming through photosynthesis. Seagrass beds in coastal ecosystems have high plant productivity and are found to have the ability to reduce the effect of global warming due to the increase of $\mathrm{CO} 2$ in the atmosphere. Due to the anthropogenic effect, decreasing environmental quality, such as tourism, may affect seagrass diversity and growth, therefore its carbon contents. This study investigates the ability of seagrass species as carbon storage and their diversity in a common tourist destination area referred to as disturbed habitat, located at Sanur and an area that is less disturbed, referred to as undisturbed habitat. Samples were collected from 3 transects $50 \mathrm{~m}$ in length that were placed on each site. Three plots, each measuring $0.5 \times 0.5 \mathrm{~m}$, were employed on each transect. The number of individuals of each species and the percent plant coverage were measured on each plot. Plant biomass and carbon content were extracted in the Lab and divided into below- and above-ground. The result shows that eight species were found at Sanur and only four from Samuh sites. On average, the percentage of plant coverage was higher at the Samuh site. Samuh site. The plant biomass and carbon storage were lower at Samuh than at the Sanur site. Species differences from each site affect the plant biomass, so the carbon content. Anthropogenic activities are not the only ones to determine the carbon storage of seagrass, but rather the species morphology.
\end{abstract}

Keywords - Carbon sequestration; global warming; seagrass; anthropogenic disturbance; Bali.

\section{INTRODUCTION}

Seagrass beds are flowering plants critical of marine habitats. It is distributed globally in tropical marine habitats and adapted to grow and reproduce submerged in seawater, usually in shallow marine waters down to a depth where about $11 \%$ of surface light still reaches the bottom [1]. Ecologically, seagrass bed has an essential role in the coastal ecosystem, such as places for migratory, feeding grounds, and nursery grounds for various marine organisms. It plays a vital role in fish ecology, and those local livelihoods were highly dependent on small-scale fishing [2], [3]. The vast amount of seagrass beds found in Indonesia contributes to the high fish species diversity [4], dugongs [5], and sea turtles [6]. The enhancement of genetic diversity has also been thought to support seagrass's resilience in the Indo Pacific regions [6], [7]. The diversity of the seagrass ecosystem has important conservation and management implications, therefore maintaining its diversity and complexity is crucial [7].

Twelve species of seagrasses in Indonesia are distributed across 293.464 ha, with the most common species being Thalassia hemprichii [8]. However, when compared with other nations, it is thought that there are more unmapped seagrass beds, and it is most likely that Indonesia has the largest distribution of seagrass beds in the world [4]. Of fifteen species found in Indonesia [8], 7 of those were found in Sanur beach alone in 2012, with a total area of $8 \mathrm{~km}^{2}$ [9]. A total of 8 species was found in a similar but wider area in Sanur beach in 2016 [10], and ten species of seagrass were 
found in three marine ecoregions of Indonesia, namely Sunda Shelf, Bintan Island, and the Seribu Island, Talaud Island of Sulawesi Sea, and Tanimbar Islands of Banda Sea [11]. The seagrass found in Bali is distributed throughout coastal regions, with the most concentrated seagrass found in the south-eastern region [12].

World global surface temperature keeps increasing with the latest annual average temperature was measured at $0.99^{\circ} \mathrm{C}$ in the year 2019, recording 19 out of the 20 warmest years since 2001 [13]. The increasing temperature or global warming are reportedly caused by greenhouse gases (GHGs) through anthropogenic activities, including land-use alteration, deforestation, biomass burning, draining of wetlands, soil cultivation, and fossil fuel combustion [14].

Seagrass plays a vital role in combating global warming. In tropical oceans, seagrass, mangroves, and coral reefs form an ocean seascape, where the three ecosystems interact with each other distributing and storing nutrients [15]. Although only occupying less than $0,2 \%$ of the ocean, seagrass beds are estimated to hold $27.4 \mathrm{TgCyr}^{-1}$, accounting for around $10 \%$ of the total organic carbon contained in the world's ocean [16]. It is estimated that $2 \%$ of blue carbon is stored in seagrass in Indonesia alone [17]. The seagrass's carbon budget estimations may often change as they are different based on their species, environment, time of year, and epiphytes that inhabit the seagrass meadows [18].

Seagrass beds are regarded as one the most efficient and long-term organic carbon sinks on earth [18], [19], but it is widely under threat [1], [20], particularly in Indonesian tropical waters [3]. Because of their role as carbon sinks, protection and restoration of seagrass meadows contribute to climate change mitigation [20]. Increasing water temperatures because of climate change may undermine their capacity to sequester and retain organic carbon $\left(\mathrm{C}_{\text {org }}\right)$ [19].

As their counterpart of terrestrial plants, seagrass synthesizes their food by utilizing the energy of light and carbon dioxide [21]. Seagrass beds, together with mangroves and coral reefs, has the role of absorbing carbon dioxide and storing it in the form of biomasses in the roots, leaves, and rhizomes [8]. The amount of carbon fixation in seagrass leaves often exceeds their immediate metabolic needs, which leads to the excess carbon produced being stored in its roots and rhizomes and eventually being released in the sediment in the form of autochthonous soil [22]. It has also been found that seagrass stems and leaves can trap suspended organic carbons in the water column [23]. The carbon absorbed and stored by seagrass beds is thought to last up to millennials making seagrass beds one of the most efficient carbon storage methods.

The leading cause of seagrass deterioration is anthropogenic activity, such as sewage disposal, destructive fishing, coastal constructions, and boat dredging [24], [25]. The poor land management and coastal development have also contributed to seagrass bed deterioration in Indo-Pacific regions [26]. In Bali, seagrass damages are mostly caused by tourism-related activities, such as boat dragging and propeller scars, mainly being caused by boat crossings between the archipelago [24], [25], [27]. It is estimated that over one-third of the world's seagrass were lost since 1879 and is continuing to disappear at the rate of $110 \mathrm{~km} 2$ per year [28].
The other cause of seagrass deterioration is eutrophication. It is considered to have the most severe impacts on seagrass beds globally [29], which is mainly caused by surface runoff and nutrient fluxes. Nutrient fluxes reduced water clarity and attenuated light [30]. These factors lead to increased growth of opportunistic macroalgae and epiphytes in the area [1]. Eutrophication and hypertrophication have been found to happen in Nusa Dua waters of Bali Island [31]. The effect of the seagrass ecosystem related to its function as carbon sequestration has been quite intensively studied [20], [32], [33], but the effect of the tourist destination has not much been considered [27]. This study aimed to investigate different species of seagrass's ability to sequestrate carbon from different habitats affected by anthropogenic activities.

\section{Material AND Method}

\section{A. Study Sites}

Sanur is a famous tourist destination in Bali located at $8^{\circ} .40^{\prime} 56^{\prime \prime}$ South, $115^{\circ} .15^{\prime} 51^{\prime \prime}$ East. Visited by the local and foreign tourists, it is located near the central city and its community center. Sanur beach is used to harbor boats that transport people from Bali Island to Nusa Penida and surrounding islands. Samuh beach, however, is located at $8^{\circ} 47^{\prime} 515^{\prime \prime}$ South, $115^{\circ} 13^{\prime} 45^{\prime \prime}$ East, relatively further away from the main city and its community center; therefore, it less visited by locals and tourists. Samples of seagrasses were collected from those two sites.

\section{B. Sample and Data Collections}

The survey was conducted to identify seagrass species growing at two sites, called Samuh and Sanur. Three 50-meter line transects were deployed perpendicular to the shoreline, and three quadrants (plots) sized $0.5 \times 0.5 \mathrm{~m}$ was placed on each side of the line transect. The transects' starting point was at the first seagrass plant found from the shoreline, where the first plot was placed. The other two plots were $25 \mathrm{~m}$ apart along the line transect, with the distance between transects was $50 \mathrm{~m}$. The individual number of each species and species coverage were counted from each plot.

Some species found were collected and transported to the laboratory to measure the biomass and carbon content. Three repetitions of samples were used in data collection for each species. The water temperature was measured in situ, but the dissolved oxygen (DO) and the water acidity was measured at the laboratory. Each plant was sorted out, cleaned, and separated between the leaves as for the above ground category and the root and rhizome as the below ground category. Each sample category of each species was weighed to obtain the fresh sample weight. Samples were placed in the oven at $70^{\circ} \mathrm{C}$ until its constant weight to gain the dried weight or mass Losson-Ignition (LOI) [34] with slight modification on temperature.

Plant biomass was measured by subtracting the weight of fresh plants from the weight of the oven-dried plant. Seagrass collection for biomass estimation was done from the set plot [35]. The total carbon of seagrass species was measured by combustion of samples in an $850-900^{\circ} \mathrm{C}$ in the combustion chamber for 24 hours or until all organic matters were burnt. The carbon ash of plant materials resulting from the 
combustion was weighed to gain the carbon content/carbon source.

\section{RESULTS AND DISCUSSION}

\section{A. Species Diversity}

Based on earlier observation data, the species of seagrass found at Samuh were four species, namely: Enhalus acoroides, Thalassia hemprichii, Cymodocea rotundata, Halodule pinifolia, and eight species were observed during the survey at the Sanur site namely: Enhalus acoroides, Thalassia hemprichii, Cymodocea rotundata, Halodule pinifolia, Cymodocea serrulata, Syringodium isoetifolium, Halophila ovalis, Thalassodendron ciliatum. Earlier studies have been conducted in 2012 at Sanur area and found seven species of seagrasses [10], while Ibnu Graha et al [11] found eight species, but one species ( $T$. ciliatum) was recorded in the current study but was not recorded in the year of 2012 or 2016. Halodule uninervis was recorded in the year 2012 and 2016 but was not recorded in the current study. Two species that have not been recorded in the study conducted in 2012 were T. hemprichii and T. ciliatum (Table 1).

Differences of species found among the year of studies are most likely due to the lack of transects deployed, where only three transects were used for each study. The new species may be growing as it may be brought by the current form of other seagrass habitats, but that is less likely since one species ( $T$. ciliatum) which was not found in 2012, and 2016 was present in the current study (2020), while the species that has been found in 2012 and 2016 (H. uninervis) was not present in the current study. Ibnu Graha et al [11] stated that the species diversity of seagrass at Sanur is on the high criteria within Indonesia. Out of 12 species seagrass species found in Indonesia in 2012 [11], 75\% was found in Sanur, and $80 \%$ of all species can be found in Bali Island.

TABLE I

THE SPECIES OF SEAGRASS RECORDED FROM 3 COLLECTIONS OF 4 YEARS APART AT SANUR SITE

\begin{tabular}{|c|c|c|c|c|}
\hline No & Species & $\begin{array}{c}\text { Study in } \\
2012 *\end{array}$ & $\begin{array}{c}\text { Study in } \\
2016^{* *}\end{array}$ & $\begin{array}{c}\text { The } \\
\text { current } \\
\text { study in } \\
\mathbf{2 0 2 0} \\
\end{array}$ \\
\hline 1 & Enhalus acoroides & $\bullet$ & $\bullet$ & $\bullet$ \\
\hline 2 & Thalassia hemprichii & - & $\bullet$ & $\bullet$ \\
\hline 3 & Cymodocea rotundata & $\bullet$ & $\bullet$ & $\bullet$ \\
\hline 4 & Halodule pinifolia & $\bullet$ & $\bullet$ & $\bullet$ \\
\hline 5 & Cymodocea serrulata & $\bullet$ & $\bullet$ & $\bullet$ \\
\hline 6 & $\begin{array}{l}\text { Syringodium } \\
\text { isoetifolium }\end{array}$ & $\bullet$ & $\bullet$ & $\bullet$ \\
\hline 7 & Halophila ovalis & $\bullet$ & $\bullet$ & $\bullet$ \\
\hline 8 & $\begin{array}{l}\text { Thalassodendron } \\
\text { ciliatum }\end{array}$ & - & - & $\bullet$ \\
\hline 9 & Halodule uninervis & $\bullet$ & $\bullet$ & - \\
\hline
\end{tabular}

Data used for analysis is based on the collected data using transect methods. Out of 8 species of seagrass observed in Sanur, only 3 species (Fig. 1) leapt into the transect. Therefore, these 3 species were observed for analysis. The 4 species that were leapt into the transect plots at Samuh all were analyzed. The substrate of both sites is sandy with dissolved oxygen (DO) was slightly higher at the Samuh site
(8.65) compared to the Sanur site $(7,70)$. The water temperature was similar at both sites $\left(32^{\circ} \mathrm{C}\right)$ as also the water acidity $(\mathrm{pH})$ was quite similar (8.21 at Sanur and 8.23 at Samuh sites).

Seagrass growth is affected by water quality. An increase in water acidity $(\mathrm{pH})$ will lower the photosynthesis rate in seagrass. The photosynthesis rate reduction was found to decrease when the water acidity is $9 \mathrm{pH}$ and above, where the optimal $\mathrm{pH}$ level for seagrass development being around 8.8 $\mathrm{pH}$, though this number varies from species to species [36]. Water acidity at both study sites is still in the range of optimal value. The same problem may occur when the water's $\mathrm{pH}$ surrounding the seagrass beds drops below the $\mathrm{pH}$ threshold, which also differs depending on the seagrass species. The lowering of the ocean's pH level is also known as acidification. Currently, the effects of ocean acidification on seagrass productivity have not been significant, although it is thought in the future, seagrass would have to up-regulate stress responses, especially those that inhabit tropical regions [37].

Temperature also plays an essential role in seagrass growth. The temperature of the waters heavily influences seagrass photosynthesis. The temperature has often been examined using Productivity-Index (P-I) curves [38], [39]. It has been found that respiration rates usually increase with the increase in temperature. The optimal temperature for seagrass growth and photosynthesis is higher in tropical/subtropical regions than in temperate regions [40]. The optimal growth temperature for seagrass species in temperate regions has been found between $11.5^{\circ} \mathrm{C}$ to $26^{\circ} \mathrm{C}$ whereas the temperature of seagrass species in tropical/subtropical regions was between $23^{\circ} \mathrm{C}$ to $32^{\circ} \mathrm{C}$ [40]. An extreme increase in water temperature due to low tide affects the photosynthesis rate of tropical seagrass. Seagrass growth is decreased if extreme water temperature occurs on six consecutive days, leading to mortality [41]. The increase or decrease in seagrass habitat in temperate, subtropical, and tropical regions would lead to the lowering of seagrass productivity, and the seagrass would also be forced to up-regulate their stress responses in order to adapt to their new habitat [37].

Concerning substrates, different seagrass species have been found to grow in the different substrates. Seagrass usually requires a soft substrate of gravel, sand, or mud, where the rhizomes and root of the plant can elongate and fasten. Some seagrass species can be found on rocky substrates, such as the Cymodocea nodosa population in the coast of Portugal that grows on a rock by inserting the roots and the rhizomes in cracks and crevices found in the rock [42]. Species of seagrass grow in different substrates may be affected by the species' ability to uptake nutrients. Seagrass growth, abundance and morphology are also linked to the availability of nutrient resources in the substrate. In northern temperate climates and habitats with terrigenous sediments, nitrogen limitation occurs in intertidal and subtidal beds [43]. Commonly, seagrass found in terrigenous sediment has an abundance of phosphorus but lack nitrogen. In tropical regions and carbonate sediments appear to experience low phosphorus limitation caused by phosphate binding in the sediment. This finding shows that substrates play an essential role in determining the limiting nutrient to seagrass growth [44). 


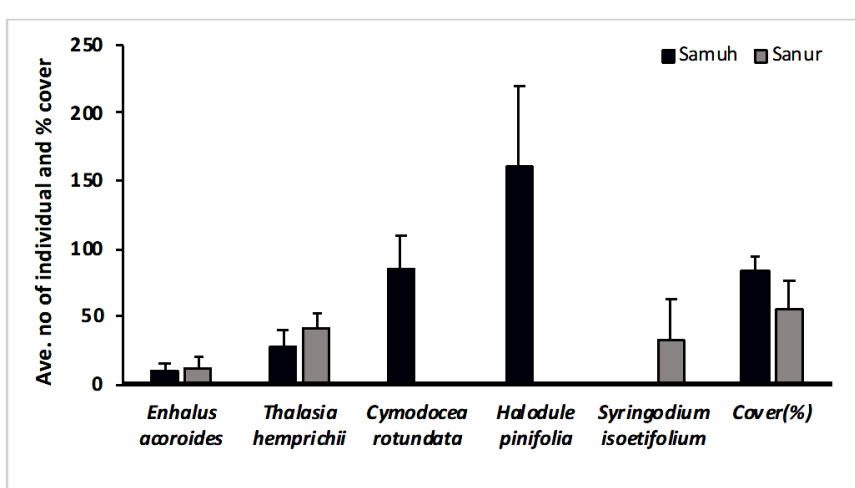

Fig. 1 Average number of individuals and percent coverage of seagrass species from Samuh and Sanur Sites

The effect of sites towards the number of individual seagrasses and its coverage (Fig. 1) was found that the total number of individual seagrass, overall, was slightly higher at Samuh compared to Sanur $(\mathrm{F}=5.393, \mathrm{df}=10, \mathrm{P} \leq 0.043)$, with the mean number of individuals was $496.83 \pm 178.87$ and at Sanur was $144.17 \pm 79.66$. In line with the number of individuals, the average percentage cover of seagrass at Samuh was $83.00 \pm 3.61$, and at Sanur, it was 56.47 \pm 5.54 , which means that the coverage of seagrass was denser at Samuh than that of Sanur $(\mathrm{F}=7.61, \mathrm{df}=28, \mathrm{p} \leq 0.01)$. The habitat condition affects the organism, such as a plant that can grow on them. The study found that the substrate of both sites was similar, with both were sandy beaches, but the number of species found was higher at the habitat where the anthropogenic activities were higher. This finding indicates that anthropogenic activities such as visiting tourists alone do not influence the species' existent, but maybe by other causes. However, the effect of other anthropogenic activities such as domestic waste that runs into the sea inevitably affects the growth of the seagrass [4], [45], [46].

The percentage coverage difference between seagrass found in Sanur Beach and Samuh Beach can be explained by the difference in tourist activity in both areas. The amount of tourist activity in Sanur Beach is considerably higher than in Samuh, and this is due to its location, which the main public highway can access. Whilst Samuh can only be accessed by a small alleyway, hence limiting public access to the beach. Another factor is the type of human activities occurring on both beaches. In Samuh, human activities are limited only to specific coastal tourism due to its isolated location within Indonesia Tourist Development Corporation (ITDC). While in Sanur, the activities range from various tourist destinations and cross-island transportation using boats in the area. Negative impact due to water transportation includes oil spills and dredging, leading to the depletion of seagrass beds in the area [27], [45]. Sanur's higher coastal activity causes disturbances in seagrass development, leading to a lower coverage percentage than Samuh. A review of the percentage of seagrass losses due to various activities has been evaluated [45]. The three most anthropogenic activities that cause seagrass loss were coastal development, land reclamation, and sedimentation due to deforestation. Other significant causes of loss include seaweed farming, sand and coral mining, and over-exploitation of associated herbivores [45]. Sedimentation caused by deforestation and excessive land use is also a threat to seagrass growth in Indonesia. Water clarity is impeded by fine particulate organic matter and fine dust brought to the shoreline, causing seagrass to stifle its leaves, reducing its ability to photosynthesis [4].

\section{B. Plant Biomass and Carbon Storage}

Seven species were collected using transect methods and found that overall seagrass biomass from Samuh was slightly lower $(1.51 \pm 0.35 \mathrm{~g})$ than Sanur $(1.78 \pm 0.59 \mathrm{~g})$. The overall above-ground biomass was $14,81 \pm 0.35$, and below-ground biomass was $17,76 \pm 0.59 \mathrm{~g}$. Interestingly, although the Samuh area has not been visited as much as at Sanur, the biomass of seagrasses was not higher as expected.

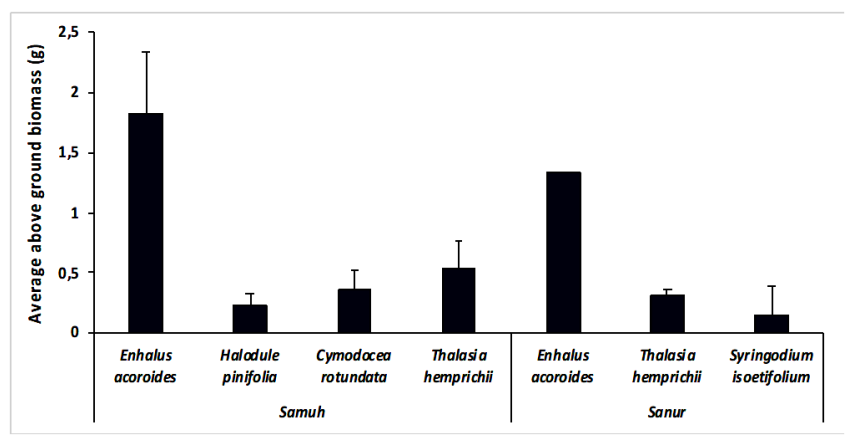

Fig. 2 Average above-ground biomass of seagrass species collected from Samuh and Sanur sites

The distribution of the above-ground biomass based on the species was found highest in E. acoroides $(1.827 \pm 0.51 \mathrm{~g})$ at both sites, and the lowest was in H. pinifolia $(0.27 \pm 0.098 \mathrm{~g})$ at Samuh and $S$. isoetifolium at Sanur sites $(0.14 \pm 0.25 \mathrm{~g})$ (Fig. 2 ). The below-ground biomass of the species collected was also highest in the E. acoroides $(7.27 \pm 0.26 \mathrm{~g})$ at both sites, and the lowest was found in H. pinifolia $(0.27 \pm 0.08 \mathrm{~g})$ at Samuh and in S. isoetifolium $(0.11 \pm 0.01 \mathrm{~g})$ in Sanur (Fig. 3).

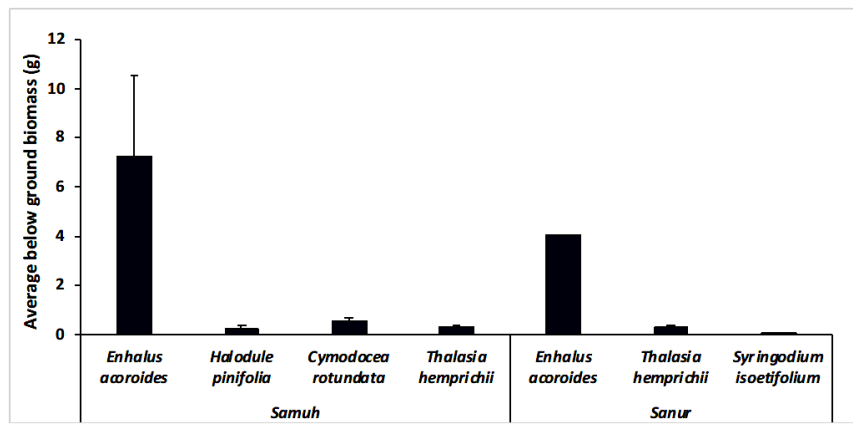

Fig. 3 Average below-ground biomass of seagrass species collected from Samuh and Sanur sites

The average carbon of seagrass was found higher at Sanur compared to Samuh (Fig. 4). The above-ground carbon content of seagrass from Samuh was $0.46 \pm 0,04 \mathrm{~g}$, and the bellow ground carbon content of seagrass species was $0.47 \pm 0.05 \mathrm{~g}$. The carbon concentration of seagrass from the Sanur site was $0.60 \pm 0.04 \mathrm{~g}$ for the above ground and $0.61 \pm 0.05 \mathrm{~g}$ for the below ground. Many studies have been conducted on the rule of seagrass on carbon sink, then reviewed by Watiniasih et al [45] that seagrass production was ended up in below-ground tissue and detritus, measuring about $15 \%$ of net $\mathrm{CO} 2$ uptake by marine organism [7]. 


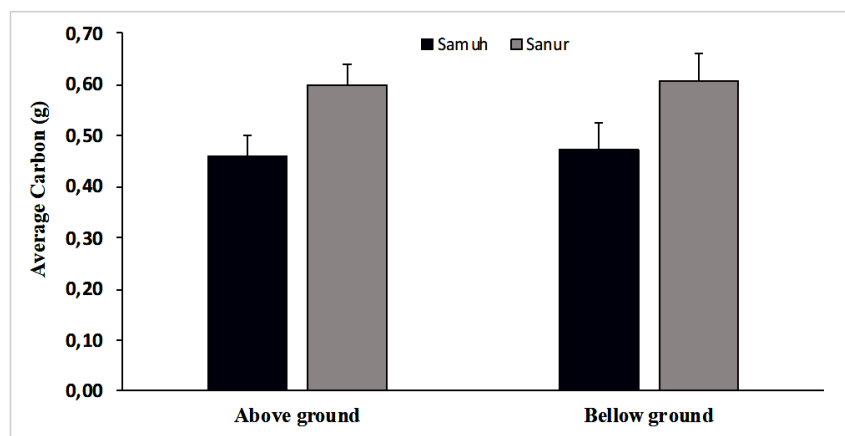

Fig. 4 Average carbon of below-ground and above-ground of seagrass at Samuh and Sanur sites

A similar study throughout Indonesia has found that $E$. acoroides has been found to have higher quantities of biomass compared to other species of seagrass, which has been argued due to their larger size [47], [48], [49]. The larger morphological size of E. acoroides can accumulate more carbon, $40 \%$ of its total biomass [50]. Contrarily, H. pinifolia and $S$. isoetifolium have a lower quantity of biomass due to their smaller morphological size of both species compared to other species present. In addition to morphological factors, other intervening factors, such as the high density of seagrass, could also affect biomass value [50]. The low below-ground biomass found in species other than E. acoroides is explained by the difference in underground morphology between plants. $E$. acoroides has a thick rhizome with thick and long roots, which stores more biomass, whilst the other plants, although some may have thick rhizomes, usually have small hair-like roots which can store less biomass [51].

It has also been found that higher below-ground biomass has the potential to increase sedimentary organic carbon $\left(\mathrm{C}_{\mathrm{org}}\right)$ deposits. The high root production causes this compared to other parts of the plant and rapid turnover time. Seagrass canopies have also been found to filter suspended organic matter and retain it in the sediment, adding to accumulated organic matter [52].

Prarikeslan et al. [53] found that the leaf had the lowest biomass (above ground) in most seagrass species studied than on its rhizome and root (below ground). The largest carbon content was recorded below ground, indicating that the root and rhizome were holding carbon at the most denser body structure than that above ground [27]. Differences in holding organic carbon were also recorded in other seagrass bed of $P$. oceanica, which was 3 times higher compared to $P$. australis due to high sediment accumulation rates and predicted due to its orthotropic way of growing (vertical rhizome growth) of $P$. oceanica and plagiotropic or rhizome growth of $P$. australis [53]. The same observation was made that a higher percentage of the carbon stored is found in the seagrass storage below ground [11], [47], [54].

The average carbon concentration of seagrass species collected from Samuh and Sanur showed that the carbon content of $\mathrm{E}$ acoroides was $0.61 \pm 0.08 \mathrm{~g}$ and in $\mathrm{H}$. ovalis was $0.44 \pm 0.04 \mathrm{~g}$ (Fig. 4). The average carbon content of the seagrass species collected from Samuh and Sanur is presented in Table 2.
TABLE II

THE AVERAGE \pm SE OF CARBON OF SEAGRASS SPECIES COLLECTED FROM SAMUH AND SANUR Sites. THE ZERo (0) VALUE REPRESENT THAT THE SPECIES WAS NOT PRESENT ON THE STUDY Site.

\begin{tabular}{|c|c|c|c|}
\hline \multirow{2}{*}{ No. } & \multirow{2}{*}{ Species } & \multicolumn{2}{|c|}{ Carbon (g) } \\
\hline & & Samuh & Sanur \\
\hline 1 & Enhalus acoroides & $0.48 \pm 0.07$ & $0.73 \pm 0.13$ \\
\hline 2 & Halodule pinifolia & $0.57 \pm 0.07$ & $0.51 \pm 0.03$ \\
\hline 3 & Thalassia hemprichii & $0.54 \pm 0.62$ & $0.63 \pm 0.08$ \\
\hline 4 & $\begin{array}{l}\text { Syringodium } \\
\text { isoetifolium }\end{array}$ & $0.37 \pm 0.68$ & $0.68 \pm 0.92$ \\
\hline 5 & Halopphila ovalis & $0.36 \pm 0.52$ & $0.52 \pm 0.05$ \\
\hline 6 & $\begin{array}{l}\text { Cymodocea } \\
\text { rotundata }\end{array}$ & $0.54 \pm 0.01$ & 0 \\
\hline
\end{tabular}

The highest biomass above and below ground parts was found in the bigger species of $E$. acoroides, which shows a similar finding to Stankovic et al. [50]. The large and medium-size species had a higher carbon content below ground, whilst smaller size species had a higher carbon content in the above-ground parts. Laffoley and Grimsditch [55] studied the seagrass carbon content at the Andaman coastal area of Thailand found that the biomass below-ground exceeded the above-ground biomass.

The higher carbon storage found below ground is mainly caused by the biomass storage system of seagrass, where a large number of seagrass species tend to store more of their biomass below ground instead of above ground. The growth pattern of seagrass also influences the carbon storage pattern of seagrass. The rhizomes and roots that are a part of the below-ground portion of seagrass have a slower rate of growth compared to other parts of the seagrass that is above ground, which results in the below-ground portion of seagrass having a higher potential of carbon storage when compared with the above-ground portion of the seagrass [47], [56]. That is another explanation for why higher carbon storage is found in E. acoroides than in any other seagrass. Organic carbon of $E$. acoroides was significantly higher than on T. hemprichii, and it was argued that it might be due to the denser the vegetation, the higher the organic carbon content of the seagrass [51].

The contribution of ocean green plants, forest and other ecosystems in stabilizing the $\mathrm{CO} 2$ concentration in the atmosphere is very substantial, although the emission of $\mathrm{CO} 2$ from fossil fuel combustion increased by $40 \%$ for 20 years, between 1980 to 2000 [57]. Their contribution is storing carbon as a carbon sink or carbon sequestration; that is the process of storing the $\mathrm{CO} 2$ from the atmosphere into the longlived $\mathrm{C}$ pools [57], such as the green plants.

Seagrass has been well known as carbon sinks by accumulating a large amount of carbon in their sediment [45], [58]. Compared to terrestrial vegetation, seagrass bed have been found to bury up to $14 \mathrm{Kg} \mathrm{C} \mathrm{m}^{-2}$ each year, which approximated to be $10-15 \%$ of the total blue carbon burial in the ocean, making seagrass beds the highest blue carbon accumulator [52], [59]. Seagrass beds, together with other marine producers (mangroves and coral reefs), form the worlds seascape and one of the largest carbon sinks in the world. It will enable carbon to be stored in the sediment for centuries and even up to millennia [52], [60].

Like other plants, seagrass captures carbon dioxide through photosynthesis. Most seagrass species are considered net 
autotrophic systems, meaning that the gross primary production of seagrass exceeds respiration. Photosynthesis supports the high primary net production with a high sequestration rate of seagrass carbon and biomass, thus causes the accumulation of seagrass biomass [61]. The amount of seagrass organic carbon $\left(\mathrm{C}_{\text {org }}\right)$ being stored in the sediment is thought to be affected by its decomposition rate, with a low decomposition rate being more favored. The efficiency of organic carbon stored in the sediment by seagrass is also determined by density, porosity and grain size, and plant uptake's energy efficiency [62]. Another factor that contributes to the high carbon sink capacity achieved by the seagrass beds is the carbon flow pathway, which is also linked to multiple intricate processes [52], such as disturbance by pollutants and the type of substances [64].

Anthropogenic activities could also affect the growth and metabolism shown by a study conducted by Karlina et al. [64]. It concluded that anthropogenic activities such as tourism could lead to seagrass meadow degradation in the form of spatial distribution, percent coverage, biodiversity, and community structure of seagrass meadows [65]. This study found that anthropogenic activities at Sanur and Samuh have affected the population density represented by plant coverage. One of the more serious issues facing seagrass conservation is ocean eutrophication. Eutrophication is the process of adding organic matter to the ocean, causing the ocean to be "rich" in nutrients. At first, it was thought that the addition of organic matters, mainly nitrogen, would positively impact the net primary production of seagrass; on the contrary, there was no significant increase in seagrass productivity [66]. Eutrophication has been found to boost algae production and growth, which threatens the seagrass population because algae are one of the seagrass competitors [67].

Furthermore, boating activities could also damage seagrass beds in the area [68] from and to Sanur beach. Boat mooring has been one of the most destructive anthropogenic activities towards the seagrass beds. It is thought that up to $16,7 \mathrm{~m}^{2}$ of seagrass beds are destroyed monthly due to boat mooring [69]. The ability of seagrass to recover from the continuous physical damage caused by boat mooring would be minimal. The damage caused to seagrass by boat mooring would lead to substantial shoot density loss or even complete removal of seagrass in the area.

Indonesian seagrass conservation initiatives have seen success in the restoration of seagrass beds across the country [9]. The success was achieved by involving the local coastal communities in restoration projects and introducing laws prohibiting the damaging of seagrass and laws those promotions of seagrass protection and conservation [4], [5]. It is widely accepted that the most effective method of seagrass conservation and restoration is by introducing customary law with traditional embedded values of marine conservation known as "sistem adat" in Indonesian and promoting localbased conservation such as those found in Papua, Gili Trawangan, and other regions across Indonesia. A notable example of seagrass conservation success in Indonesia is found in Wakatobi National Park, where a local NGO had successfully led an incentive scheme to restore riparian vegetation, including seagrass and other species, to reduce runoff and sedimentation occurring in the area. There has also been an increase in seagrass-friendly mooring systems, which aims to minimize direct contact with seagrass on the seabed. It has also been demonstrated that less damaged was done to seagrass meadows by using environmentally friendly boat mooring when compared to traditional swing mooring [4], [69], [70]. Exact management programs have been implemented in many countries such as in Texas, USA, those are 1) seagrass restoration, enhancement, and creation; 2) dredging and shoreline development; 3) policy consistency; and 4) research, data acquisition, and monitoring, which is under Federal Government Policy [71].

\section{CONCLUSION}

Seagrass grows in Sanur was more diverse than that of Samuh. The plant biomass and carbon storage were higher at Sanur than at Samuh. The heavier anthropogenic activities at Sanur did not affect the diversity, biomass, and carbon storage, rather the seagrass morphology.

\section{REFERENCES}

[1] C.M. Duarte, "The future of seagrass meadows" Environmental Conservation,vol. 29, pp. 192-206, 2002.

[2] Azkab M, "Struktur dan Fungsi pada Komunitas Lamun," Jurnal Oseana, vol. 25 no. 3, pp. 9-17, 2000.

[3] A. Syukur, Y. Wardiatno, I. Muchsin and M. M. Kamal, "Threats to Seagrass Ecology and Indicators of the Importance of Seagrass Ecological Services in the Coastal Waters of East Lombok, Indonesia," American Journal of Environmental Sciences, vol. 13, no. 3, pp. 251265. Mar 2017, DOI: 10.3844/ajessp.2017.251.265.

[4] R. K. F. Unsworth, R. Ambo-Rappe, B. L. Jones, Y. A. La Nafie, A. Irawan, U.E. Hernawan, A. M. Moore, L. C. Cullen-Unsworth. "Indonesia's globally significant seagrass meadows are under widespread threat", Science of the Total Environment, vol. 634, pp. 279-286. Mar 2018. DOI: 10.1016/j.scitotenv.2018.03.315

[5] J. Schipper, J. S. Chanson, F. Chiozza, N. A. Cox, M. Hoffmann, V. Katariya, et al., "The status of the world's land and marine mammals: diversity, threat, and knowledge," Science, vol. 322, pp. 225-230. 2008

[6] M. R. Heithaus, T. Alcoverro, R. Arthur, D. A. Burkholder, K. A Coates, M. J. A. Christianen, M. J. A., et al., "Seagrass in the age of sea turtle conservation and shark overfishing," Frontier Marine Science. Aug 2014.1:28. doi: 10.3389/fmars.2014.00028

[7] J. E. Duffy, "Biodiversity and the functioning of seagrass ecosystems," Marine Ecology Progress Series, vol.311, pp. 233-250. Apr 2006

[8] C. M. Duarte, C. L. Chiscano, "Seagrass biomass and production: a reassessment," Aquatic Botany 65:159-174, 1999.

[9] U. E. Hernawan, N. D. M. Sjafrie, I. H. Supriyadi, Suyarso, M. Y. Iswari, K. Anggraini, Rahmat, Status Padang Lamun Indonesia 2017, Puslit Oseanografi - LIPI, Rahmat -Jakarta,2017.

[10] I W. Arthana, "Jenis dan kerapatan padang lamun di Pantai Sanur Bali," Bumi Lestari Journal of Environment, vo. 5, no. 2, Nov. 2012. https://ojs.unud.ac.id/index.php/blje/article/view/2409.

[11] Y. Ibnu Graha, I. W. Arthana, and I. W. G. Astawa Karang, "Simpanan Karbon Padang Lamun Di Kawasan Pantai Sanur, Kota Denpasar," Ecotrophic J. Ilmu Lingkung. (Journal Environ. Sci., vol. 10, no. 1, p. 46, May 2016, doi: 10.24843/EJES.2016.v10.i01.p08.M. Kawaroe, A. H. Nugraha, Juraij, I. A. Tasabaramo, "Seagrass biodiversity at three marine ecoregions of Indonesia: Sunda Shelf, Sulawesi Sea, and Banda Sea," Biodiversitas, vol. 17, no. 2, Oct 2016.

[12] The NASA Gov. website. [Online]. Aug 2020Available at: https:/climate.nasa.gov/vital-signs/global-temperature

[13] R. Lal, "Carbon sequestration," Philosophical Transactions of the Royal Society B: Biological Sciences, vol. 363, no. 1492, pp. 815-830, Mar 2008, DOI: 10.1098/rstb.2007.2185

[14] J. C. Ogden, E. H. Gladfelter, "Coral reefs, seagrass beds and mangroves:their interactions in the coastal zones of the caribbean," UNESCO Reports on Marine Science vol. 23, p.133, 1983.

[15] J. W. Fourqurean, C. M. Duarte, H. Kennedy, N. Marbà, M. Holmer, M. A. Mateo, E. T. Apostolaki, G. A. Kendrick, D. Krause-Jensen, K J. McGlathery, O. Serrano, "Seagrass ecosystems as a globally 
significant carbon stock," Nature Geoscience, vol. 5, no. 7, pp. 505509. May 2012. DOI: 10.1038/ngeo1477

[16] D. M. Alongi, D. Murdiyarso, J. W. Fourqurean, J. B. Kauffman, A. Hutahaean, S. Crooks, C. E. Lovelock, J. Howard, D. Herr, M. Fortes, E. Pidgeon, T. Wagey, "Indonesia's blue carbon: a globally significant and vulnerable sink for seagrass and mangrove carbon," Wetlands Ecology and Management, vol. 24, no. 1, pp. 3-13. Jul 2015 DOI: 10.1007/s11273-015-9446-y

[17] P. I. Macreadie, M. E. Baird, S. M. Trevathan-Tackett, A.W.D Larkum,.; P. J Ralph, Quantifying and modelling the carbon sequestration capacity of seagrass meadows-a critical assessment. Mar. Pollut. Bull. vol. 83, pp. 430-439, Jun 2014 [CrossRef] [PubMed] 2014.

[18] P. I. Macreadie and S. S. S. Hardy, "Response of Seagrass "Blue Carbon' Stocks to Increased Water Temperatures," Diversity, vol. 10, no. 115 , Oct. 2018, Doi:10.3390/d10040115

[19] I. Mazarrasa, J. Samper-Villarreal, O. Serrano, P. S. Lavery, C. E. Lovelock, N. Marbà, C. M. Duarte, J. Cortés. Habitat characteristics provide insights of carbon storage in seagrass Meadows, Marine Pollution Bulletin Jan. 2018, DOI: 10.1016/j.marpolbul.2018.01.059.

[20] M. Dahl, D. Deyanova, L. D. Lyimo, J. Naslund, G. S. Samuelsson, M. S. P. Mtolera, M. Bjork, and M. Gullstrom, "Effects of shading and simulated grazing on carbon sequestration in a tropical seagrass meadow," Journal of Ecology, vol. 104, pp. 654-664, Feb. 2016,

[21] C. M. Duarte and J. Cebrian, "The fate of marine autotrophic production," Limnology and Oceanography, vol. 41, pp.1758-1766, 1996.

[22] J. L. Howard, A. Perez, C. C. Lopes, J. W. Fourqurean, "Fertilization Changes Seagrass Community Structure but not Blue Carbon Storage: Results from a 30-Year Field Experiment," Estuaries and Coasts, pp. 1-13, Feb. 2016. DOI: 10.1007/s12237-016-0085-1

[23] G. Roca, T. Alcoverro, D. Krause-Jensen, T. J. S. Balsby, M. M. van Katwijk, N. Marbà, R. Santos, R. Arthur, O. Mascaró, Y. FernándezTorquemada, "Response of seagrass indicators to shifts in environmental stressors: A global review and management synthesis," Ecological Indicators, vol. 63, pp. 310-323, Dec 2015, DOI: https://doi.org/10.1016/j.ecolind.2015.12.007.

[24] P. L. A. Erftemeijer, R. R. R. Lewis, "Environmental impacts of dredging on seagrass: A review," Marine Pollution Bulletin, vol. 52, no. 12 , pp. 1553-1572, 2006, DOI: 10.1016/j.marpolbul.2006.09.006.

[25] R. K. F. Unsworth, and L. C. Cullen. "Recognising the necessity for Indo-Pacific seagrass conservation," Conserv. Lett, vol. 00, pp. 1-11, Jan 2010, DOI: 10.1111/j.1755-263X.2010.00101.x.

[26] N. L. Watiniasih, I. W. Nuarsa, I. M. Merdana, I. N. Budiarsa, A. Dharma, I. N. G. Antara, M. W. Poborini, "Organism Associated with Cymodocea Serulata in Different Habitats near Urban Coastal Area," IOP Conference Series: Earth and Environmental Science, vol. 396, no. 1, Nov 2019, DOI: 10.1088/1755-1315/396/1/012006.

[27] E. Mcleod, G. L. Chmura, S. Bouillon, R. Salm, M. Björk, C.M Duarte, C. E. Lovelock, W. H Schlesinger, B. R Silliman, “A blueprint for blue carbon: toward an improved understanding of the role of vegetated coastal habitats in sequestering CO2," Frontiers in Ecology and the Environment, vol. 9, pp. 552-560. Jan 2011, DOI: 10.1890/110004.

[28] P. J. Ralph, M. J. Durako, S. Enriquez, C. J. Collier, M. A. Doblin, "Impact of light limitation on seagrass," Journal of Experimental Marine Biology and Ecology, vol. 350, pp. 176-193, Nov 2007, DOI: doi.org/10.1016/j.jembe.2007.06.017.

[29] M. A. Hemminga, "The root/rhizome system of seagrass: an asset and a burden," Journal of Sea Research, vol. 39, pp. 183-196, Jun 1998, DOI: 10.1016/S1385-1101(98)00004-5.

[30] Suteja Y, Dirgayusa IGNP, "Detection of Eutrophication in Benoa Bay - Bali,” Omnia Aquatica, vol. 14, no. 3, pp 18-25. Nov 2018.

[31] D. Koopmans, M. Holtappels, A. Chennu, M. Weber, D. de Beer, "The response of seagrass (Posidonia oceanica) meadow metabolism to $\mathrm{CO} 2$-levels and hydrodynamic exchange determined with aquatic eddy covariance," Biogeosciences Discussions 2018, pp 1-23. Apr 2018, DOI: 10.5194/bg-2018-199, 2018.

[32] R. Chowdhury, P. J. Favas, M. P. Jonathan, P. Venkatachalam, P. Raja, S. K. Sarkar, "Bioremoval of trace metals from rhizosediment by mangrove plants in Indian Sundarban Wetland". Marine pollution bulletin, vol. 124 no. 2, pp. 1078-1088. Nov 2017. DOI: 10.1016/j.marpolbul.2017.01.047

[33] D. W. Nelson and L. E. Somers, Total Carbon, Organic Carbon, and Organic Matter, In Methods of Soil Analysis, Part 3. Chemical Methods, 1996.
[34] S. English, C. Wilkinson and V. Baker, Survey Manual for Tropical marine Resource, 2nd Ed. Australian Institute Of Marine Science, Townsville, 1997

[35] O. Invers, J. Romero, M. Pérez, "Effects of $\mathrm{pH}$ on seagrass photosynthesis: a laboratory and field assessment," Aquatic Botany, vol. 59, no. 3, pp. 185-194, Aug 1997.

[36] M. Koch, G. Bowes, C. Ross, X. H. Zhang, "Climate change and ocean acidification effects on seagrasses and marine macroalga," Global change biology, vol. 19, no. 1, pp. 103-132. Jul 2012, DOI: 10.1111/j.1365-2486.2012.02791.x.

[37] D. A. Bulthuis, "Effects of temperature on photosynthesis and growth of seagrasses," Aquatic Botany, vol. 27, no. 1, pp. 27-40, Jun 1986, DOI: 10.1016/0304-3770(87)90084-2.

[38] S. Z. Herzka, K. H. Dunton, "Seasonal photosynthetic patterns of the seagrass Thalassia testudinum in the western Gulf of Mexico," Marine ecology progress series, vol. 152, pp. 103-117. Jun 1997, DOI: $10.3354 /$ meps 152103 .

[39] K. Lee, S. R. Park, Y. K. Kim, "Effects of irradiance, temperature, and nutrients on growth dynamics of seagrasses: A review," Journal of Experimental Marine Biology and Ecology vol. 350, pp. 144-175, Jun 2007.

[40] C.J. Collier and M. Waycott, "Temperature extremes reduce seagrass growth and induce mortality," Mar. Pollut. Bull, 2014, DOI: 10.1016/j.marpolbul.2014.03.05

[41] J. Borum, C. M. Duarte, D. Krause-Jensen and T. M. Greve, European seagrasses: an introduction to monitoring and management, The M\&MS project, Sep 2004, http://www.seagrasses.org

[42] A. Yunitha, Y. Wardiatno, F. Yulianda, "Substrates diameter and seagrass species in bahoi coastal north minahasa: a correlation analysis,” Jurnal Ilmu Pertanian Indonesia, vol. 19, no. 3, pp. 130 135, Dec 2014.

[43] F. T. Short, Effects of sediment nutrients on seagrasses: literature review and mesocosm experiment, Aquatic Botany, vol. 27 pp. 41-57, Jun 1987.

[44] C. M. Duarte, D. Krause-Jensen, . Export from seagrass meadows contributes to marine carbon sequestration. Frontiers in Marine Science, vol. 4, pp. 13, Jan 2017, DOI: 10.3389/fmars.2017.00013.

[45] N. L.Watiniasih, I G. H. Purnama, G. Padmanabha, I M. Merdana, I N. G. Antara," Managing laundry wastewater," in IOP Conf. Series: Earth and Environmental Science, 2019, paper 248, 012084

[46] A. H. Nugraha, M. Kawaroe, E. S. Srimariana, I. Jaya, D Apdillah, S. R. Deswati, "Carbon storage in seagrass meadow of Teluk BakauBintan Island," In IOP Conference Series: Earth and Environmental Science, vol. 278 no. 1, pp. 012051, May 2019, DOI: :10.1088/17551315/278/1/012051.

[47] T. Husodo, S. D. Palabbi, O. S. Abdoellah, M. Nurzaman, N. Fitriani, R. Partasasmita, "Seagrass diversity and carbon sequestration: Case study on Pari Island, Jakarta Bay, Indonesia," Biodiversitas Journal of Biological Diversity, vol. 18, no. 4, pp. 1596-1601, Oct 2017. DOI: 10.13057/biodiv/d180438.

[48] Y. P. Rahayu, T. Solihuddin, M. A. Kusumaningtyas, R. N. A. Ati, H L. Salim, T. Rixen, A. A. Hutahaean, "The Sources of Organic Matter in Seagrass Sediments and Their Contribution to Carbon Stocks in the Spermonde Islands, Indonesia," Aquatic Geochemistry, vol. 25, no. 34, pp. 161-178, Sept 2019. DOI: 10.1007/s10498-019-09358-7.

[49] F. A. Rahman, I. qayim, Y. wardiatno, "Carbon storage variability in seagrass meadows of Marine Poton Bako, East Lombok, West Nusa Tenggara, Indonesia," Biodiversitas Journal of Biological Diversity, vol. 19, no. 5, pp. 1626-1631, Sept 2018. DOI: 10.13057/biodiv/d190505.

[50] M. Stankovic, J. Panyawai, K. Jansanit, T. Upanoi, A. Prathep, "Carbon content in different seagrass species in Andaman Coast of Thailand," Sains Malaysiana, vol. 46 no. 9, pp. 1441-1447. Sep 2017, DOI: $10.17576 / \mathrm{jsm}-2017-4609-12$.

[51] M. Gullström, L. D. Lyimo, M. Dahl, G. S. Samuelsson, M. Eggertsen, E. Anderberg, L. M. Rasmusson, H. W. Linderholm, A. Knudby, S. Bandeira, L. M. Nordlund, M. Bjork, "Blue carbon storage in tropical seagrass meadows relates to carbonate stock dynamics, plantsediment processes, and landscape context: insights from the western Indian Ocean,” Ecosystems, vol. 21 no. 3, pp. 551-566. Jul 2017.

[52] K. I. Kondoy, "Seagrass as carbon holder in Waleo coastal waters, North Sulawesi, Indonesia," AACL Bioflux, vol. 10 no. 5, pp. 13421350, 2017.

[53] W. Prarikeslan, D. Hermon, Y. Suasti, A. Putra, "Density, coverage and biomass of seagrass ecosystem in the Lobam Island, Bintan Regency-Indonesia," In IOP Conference Series: Earth and 
Environmental Science, vol. 314, no. 1, pp. 012024, Aug 2019, DOI: 10.1088/1755-1315/314/1/012024.

[54] O. Serrano, P. S. Lavery, L. Lopez-Merino, E. Ballesteros, M. A. Mateo, "Location and associated carbon storage of erosional escarpments of seagrass Posidonia mats," Frontiers in Marine Science, vol. 3, no. 42, Mar 2016, DOI: 10.3389/fmars.2016.00042.

[55] D. Laffoley, G. D. Grimsditch, "The management of natural coastal carbon sinks, "International Union for Conservation of Nature (IUCN), 2009.

[56] R. Lal, "Carbon sequestration," Philosophical Transactions of the Royal Society B: Biological Sciences, vol. 363, no. 1492, pp. 815-830, Mar 2008, DOI: 10.1098/rstb.2007.2185

[57] J. W. Fourqurean, C. M. Duarte, H. Kennedy, N. Marbà, M. Holmer, M. A. Mateo, E. T. Apostolaki, G. A. Kendrick, D. Krause-Jensen, K. J. McGlathery, O. Serrano, "Seagrass ecosystems as a globally significant carbon stock," Nature Geoscience, vol. 5, no. 7, pp. 505509. May 2012. DOI: 10.1038/ngeo1477

[58] M. N. Githaiga, A. M. Frouws, J. G. Kairo, M. Huxham, "Seagrass removal leads to rapid changes in fauna and loss of carbon," Frontiers in Ecology and Evolution, vol. 7, pp 62, Mar 2019, DOI: 10.3389/fevo.2019.00062

[59] M. Huxham, D. Whitlock, M Githaiga, A. Dencer-Brown, "Carbon in the coastal seascape: how interactions between mangrove forests, seagrass meadows and tidal marshes influence carbon storage," Current forestry reports, vol. 4 no. 2, pp. 101-110. Apr 2018, DOI: 10.1007/s40725-018-0077-4.

[60] C. M. Duarte, N. Marbà, E. Gacia, J. W. Fourqurean, J. Beggins, C. Barrón, E. T Apostolaki, E. T, "Seagrass community metabolism: Assessing the carbon sink capacity of seagrass meadows," Global Biogeochemical Cycles, vol. 24, no. 4, Dec 2010, DOI: 10.1029/2010GB003793.

[61] M. Dahl, D. Deyanova, S. Gütschow, M. E. Asplund, L. D. Lyimo, V. Karamfilov, R. Santos, M Bjork, M. Gullström, "Sediment properties as important predictors of carbon storage in Zostera marina meadows: a comparison of four European areas," PLoS One, vol. 11, no. 12, Dec 2016. DOI: 10.1371/journal.pone.0167493.
[62] A Dharma, N Budiarsa, N Watiniasih and N G Antara, "No Cost Low Cost Compressed Air System Optimization in Industry," Journal of Physics: Conference Series, vol. 989, Nov. 2017, https://doi.org/10.1088/1742-6596/989/1/012002

[63] I. N. Budiarsa, I N. G. Antara, I M G Karohika, I W. Widhiada, \& N. L. Watiniasih, "Identification Plastic Properties of Spot Welded Joints Using the Instrumented Indentation Technique, IOP Conference Series: Materials Science and Engineering, 2020, https://doi.org/10.1088/1757-899X/811/1/012020

[64] I. Karlina, F. Kurniawan, F. Idris, "Pressures and Status of Seagrass Ecosystem in the Coastal Areas of North Bintan, Indonesia," EDP Sciences, vol. 47, pp. 04008, Aug 2018, DOI: 10.1051/e3sconf/20184704008.

[65] Y. X. Ow, N. Vogel, C. J. Collier, J. A. M. Holtum, F. Flores, S Uthicke, "Nitrate fertilisation does not enhance CO 2 responses in two tropical seagrass species," Scientific reports, vol. 6, pp. 23093. Mar 2016, DOI: 10.1038/srep23093.

[66] P. M. Glibert, "Eutrophication, harmful algae and biodiversityChallenging paradigms in a world of complex nutrient changes," Marine Pollution Bulletin, vol. 124, no. 2, pp. 591-606, Nov 2017 DOI: 10.1016/j.marpolbul.2017.04.027.

[67] O. Serrano, P. S. Lavery, L. Lopez-Merino, E. Ballesteros, M. A Mateo, "Location and associated carbon storage of erosional escarpments of seagrass Posidonia mats," Frontiers in Marine Science, vol. 3, no. 42, Mar 2016, DOI: 10.3389/fmars.2016.00042.

[68] T. M. Glasby, G. West, "Dragging the chain: Quantifying continued losses of seagrasses from boat moorings," Aquatic Conservation: Marine and Freshwater Ecosystems, vol. 28 no. 2, pp. 383-394. Mar 2018, DOI: 10.1002/aqc.2872.

[69] L. C. Cullen-Unsworth, L. M. Nordlund, J. Paddock, S. Baker, L. J. McKenzie, R. K. F. Unsworth," "Seagrass meadows globally as a coupled social-ecological system: Implications for human wellbeing," Pollut. Bull. 2013), http://dx.doi.org/10.1016/j.marpolbul.2013.06.001

[70] A. Sansom, G. Mauro, J.A. "Saitas. Seagrass conservation plan for Texas," Texas Parks and Wildlife. 